\title{
Interactive comment on "Recognition of spatial framework for water quality and its relation with land use/cover types from a new perspective: $A$ case study of Jinghe Oasis in Xinjiang, China" by Fei Zhang et al.
}

Fei Zhang et al.

zhangfei3s@163.com

Received and published: 11 January 2018

Dear Referee \#1: Thanks for the editor's comments and authors have tried our best to revise the manuscript (Manuscript number: nhess-2017-358) based on their suggestions. Please see the attachment files 'Replies to the comments and suggestions' and 'revised manuscript with changes marked', if the modification meets your requirements, I will upload to the submission system. Meanwhile, the authors appreciate Editor's/Reviewer's time and consideration of our work. We strongly believe that the revised version meet the high standards set by the journal. Once again, thank you very

Printer-friendly version

Discussion paper 
much for your comments and suggestions. All in all, if you have any questions about our paper, please contact with me as follow address: E-mail:zhangfei3s@163.com Thanks NHESSD very much, and I'm looking forward to receiving your reply. Best wishes and warmly regards for you.

Sincerely yours Fei ZHANG 11th, Jan., 2018

Interactive

comment

Please also note the supplement to this comment:

https://www.nat-hazards-earth-syst-sci-discuss.net/nhess-2017-358/nhess-2017-358AC5-supplement.pdf

Interactive comment on Nat. Hazards Earth Syst. Sci. Discuss., https://doi.org/10.5194/nhess2017-358, 2017. 